\title{
SCIENTIFIC HORIZONS
}

Journal homepage: https://sciencehorizon.com.ua

Scientific Horizons, 24(2), 37-46

UDC 630*228:633.872(477.44)

DOI: $10.48077 /$ scihor.24(2).2021.37-46

\section{CHARACTERISTICS OF NATURAL OAK FORESTS OF IN SE "KHMILNYTSKE LISOVE HOSPODARSTVO" AND IMPLEMENTATION OF MEASURES FOR THEIR REGENERATION}

\author{
Oleh Vasylevskyi ${ }^{1}$, Ihor Neyko ${ }^{1}$, Yurii Yelisavenko ${ }^{1}$, Mykhailo Matusiak $^{2 *}$ \\ ${ }^{1}$ SE "Vinnytsia Forest Research Station" \\ 21036, 39 Maksymovych Str., Vinnytsia, Ukraine \\ ${ }^{2}$ Vinnytsia National Agrarian University \\ 21008, 3 Soniachna Str., Vinnytsia, Ukraine
}

\section{Article's History:}

Received: 09.03.2021

Revised: 15.04.2021

Accepted: 10.05.2021

\section{Suggested Citation:}

Vasylevskyi,O.,Neyko,I.,Yelisavenko,Yu., \& Matusiak, M.(2021).Characteristics of natural oak forests of in SE "Khmilnytske lisove hospodarstvo" and implementation of measures for their regeneration. Scientific Horizons, 24(2), 37-46.
Abstract. As a consequence of the intensive economic use of oak forests in the region, the share of stands of natural origin is significantly reduced, which requires an in-depth study of their condition, productivity, and natural restoration processes. The purpose of this study is to investigate the state, structure, and reforestation processes of oak forests for their further natural reproduction. Generally accepted methods in forestry and comparative ecology were used to compare the dynamics and condition of the studied stands with the reference ones. The paper presents the findings of the study of the productivity and state of natural forests within the state enterprise "Khmilnytske lisove hospodarstvo". It was found out that natural oak stands are represented by 7 forest types, mainly in fresh hornbeam oak forest (area - 471 hectares). According to the results obtained, it was found that natural oak stands of vegetative origin predominate within the studied enterprise (528.6 ha). They are mainly represented by forests of the $11^{\text {th }}$ age class $(188.0 \mathrm{ha})$. High-bonitat oak forests of the $1^{\text {st }}$ quality class predominate. Mature and over-mature stands have slightly lower productivity ( $2^{\text {nd }}$ quality class, stand density of $\left.0.6-0.7\right)$. The largest total reserve is characterised by stands of the $11^{\text {th }}$ age class. The maximum average reserves are typical for stands of the $9^{\text {th }}$ age class $\left(290 \mathrm{~m}^{3} / \mathrm{ha}\right)$. The greatest share of oak in stand composition (9-10 units) was found in stands of 9-10 age classes. The study shows that the natural renewal of oak is concentrated mainly in fresh sudubrava (fresh hornbeam sudubrava) in plantings in the presence of Scots pine and common oak. The density of natural renewal is 1-3 thousand units/ha. The practical value of the study is conditioned by the possibility of introducing the basic principles of forestry aimed at growing stable high-yield stands of common oak through more complete utilisation of natural renewal

Keywords: common oak, natural plantings, modal stands, high-bonitat stands, forest types, reforestation, natural regeneration

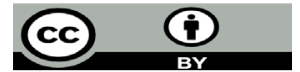

Copyright @ The Author(s). This is an open access article distributed under the terms of the Creative Commons Attribution License 4.0 (https://creativecommons.org/licenses/by/4.0/) 


\section{INTRODUCTION}

Oak forests (Quercus spp.) are recognised by the European community as one of the most significant in the history of mankind and world culture [1]. These forests are formed by highly-priced stands, which have had a significant impact in the historical aspect of providing the means of life to humanity in its natural space [2]. The presence of old-aged oak trees is one of the most well-known features of temperate forests [2-4]. Oak forests are also important for preserving biodiversity in many countries and regions, as they support the viability of a large number of living organisms, as well as animal populations that largely depend on the seed productivity of trees $[5 ; 6]$. An important aspect is the influence of animals on the spread of acorns, in particular, birds and mouse-like rodents, which contribute to the creation of new trees and plantings [2; 7]. Old-aged oak trees with thick bark and hollow trunks are particularly important for maintaining the population of invertebrates, fungi, lichens and mosses [8; 9]. Up to 1,500 species can be localised on old oak trees [10], many of which are Red Book species [11].

At a young age, there is significant competition between herbaceous vegetation and shrubs or related tree species. European hornbeam has a significant impact in the region. Researchers note a significant impact of other tree species depending on the forest type and associated species [12-15]. These competitive relationships significantly increase in more fertile environments and become extreme.

Along with hornbeam and maple, beech in its respective forest site types can be an extremely influential competitor. In particular, such trends were observed in the foothill zone. These trends are also found in European forests [12]. Common oak is rather demanding for lighting $[13 ; 16 ; 17]$ and largely depends on lighting for its successful natural regeneration[14-16; 18].

Natural renewal of oak by seed in deciduous forests dominated by shade-tolerant species is often very limited or absent altogether. So, oak, as a tree species, is mainly considered as not able to recover in natural conditions [1; 7]. In European countries, mass drying and deterioration of oak trees often occurs, which leads to a decrease in their share in the structure of forest stands.

The share of oak stands in European countries varies. In Ukraine, the share of oak forests is one of the largest - up to $40 \%$. Oak forests in Sweden account for $1.2 \%$ of the total forest area. Oak stands are common in a wide range of growing conditions. Natural regeneration can occur in pine stands, dry conditions with high soil acidity, as well as in deciduous forests on rich or wellmoistened soils. Often, a sufficient amount of natural oak regeneration can be observed in pine forests [19].

In Europe, tendencies of deterioration and drying of oak stands are often observed. It is believed that the deterioration and drying of oak stands is conditioned by the influence of pathogenic organisms, pollution, climatic influences, in particular, drought. Degradation and drying of natural oak stands is not considered catastrophic if $0.5-3.0 \%$ of trees fall off [20]. According to research by Swedish scientists in the southern part of the country, the annual decline of oak trees averaged $1.7 \%$ or lower (1.1\%) for stands aged 200 years or more. With the growth of the share of oak trees in the plantation, the dropout increases to $3.2 \%$ [3; 20].

The illumination intensity in the shaded areas of the oak stands can be at the level of $1 \%$ relative to the illumination intensity of the open space. Successful renewal by seeds requires about $20 \%$ illumination relative to the open space $[6 ; 21 ; 22]$. Partial drying in oak forests leads to the establishment of a mosaic structure and breaks in the shaded areas. Often, significant periodic drying of old-aged trees in oak forests is considered as a factor of their further natural regeneration [20]. Partial damage to oak forests by pests, diseases, and other factors can contribute to the activation of recovery processes [13; 23].

Intensive drying and degradation of oak stands can lead to successive changes in forest ecosystems [24]. Significant damage to forest stands and outbreaks of bacterial diseases, in particular Dutch elm disease, can significantly change the species composition of deciduous, in particular, oak forests. However, the development of gaps in the tents of forest stands can be an alternative to activating the growth and development of oak forests and their subsequent genesis [21].

The purpose of this study was to investigate the state, structure, and reforestation processes of oak forests for their further natural reproduction.

\section{LITERATURE REVIEW}

The problem of balanced forest management based on the principles of close to nature forestry is relevant in the context of modern challenges regarding the growth of the level of anthropogenesis of the environment and the deterioration of forest ecosystems. To date, several regional strategies have been developed in accordance with the specifics of forestry in Europe, North America, Africa, Asia and tropical countries [25-27]. The strategy of sustainable forestry management was also adopted in Ukraine [28-31]. Forestry management today is regulated by appropriate criteria and indicators [25-31]. These criteria ensure the most environmentally oriented forest management. Despite this, management in forests of natural or artificial origin does not differ [32].

Unfortunately, Ukraine lacks or has a limited legal framework for natural forests, their identification and use. In recent years, only the first steps have been taken to identify them in the Carpathian region [32]. However, there are currently no clear criteria and indicators for identifying such forests. There are also no developed criteria for assessing their condition and genesis. The basics of management and economic activity in natural forests in Ukraine have not been developed. Measures 
for the use, conservation, and extended reproduction of natural forests should be carried out in the context of forest-type zoning, types of forest-growing conditions and types of forest [33]. The main focus in the economic use of natural forests should be on their natural regeneration [34-37].

The common one enters the reproduction period as early as the age of 10 . Earlier fruiting is typical for related and clone plantations [38]. The maximum seed productivity in oak stands is observed in 50-60 years [14]. Gradually, the seed yield increases, reaching a maximum in the ripening age and early ripeness period. The high germination rate of oak seeds contributes to the appearance of seedlings in the amount necessary for the restoration of populations and cyclical alternation of generations.

Most Ukrainian researchers consider the lack of illumination to be the main reason for unsatisfactory natural regeneration $[14 ; 15 ; 36 ; 37]$. For successful growth and development of self-seeding, sufficient lighting for plant stand should be provided, which is optimal for the canopy density of 0.6-0.7 and below [14]. Most foreign scientists also consider a sufficient level of illumination to be the key factor in the successful natural regeneration of common oak [12; 16-18].

Other factors are competition, as a result of which self-seeding of oak can be largely suppressed, stunted and dried out. At a young age, there is significant competition between herbaceous vegetation and shrubs or associated tree species. European hornbeam has a significant impact in the region. Researchers note a significant impact of other tree species depending on the forest site type and associated species. These competitive relationships significantly increase in more fertile environments and become extreme [12-17]. Along with hornbeam and maple, beech in its respective forest site types can be an extremely influential competitor. In particular, such trends were observed in the foothill zone. These trends are also found in European forests [12].

In low-density plantings, the dryness of the forest floor has a negative impact on the emergence of oak seedlings [40]. Some studies note the possibility of natural regeneration of common oak after continuous logging [41]. According to the majority of the authors, an important aspect of the natural regeneration of stands is the presence of active fruiting, timely care [2; $6 ; 14 ; 16 ; 36 ; 41 ; 42]$.

\section{MATERIALS AND METHODS}

The study was conducted during 2018-2020. The work included performing both desk and field research. The survey of the forest fund and characteristics of natural oak forests was carried out by analysing the forest management materials of the enterprise (mensurational descriptions, forest inventory map, etc.). Characteristics of the structure of natural oak forests is based on the analysis of the management plan of SE "Khmilnytske lisove hospodarstvo". When dividing plantings by forest types, the developed methodological approaches and the established list of forest types were used [33]. The distribution of forest stands by origin (artificial, natural, seed, regrowth) was carried out based on the available information from mensurational descriptions in the context of each forestry. Information on the distribution of forest sites within forest-type regions, districts and sectors was also used. Determination of forest types was carried out in accordance with the given list [33]. Based on the mensurational descriptions, a sample was also made of sites older than 120 years, which are particularly important centres of biodiversity conservation. The analysis of optimal and modal stands was performed graphically based on forest management materials and regulatory data [43].

In some areas, temporary test areas (TA) were established according to generally accepted taxation methods [44] with additional determination of qualitative indicators in accordance with the methodological developments [32]. The land plots were linked to geographical coordinates (using GPS) and to the quarterly network. For each tree on the test area, the following were determined: trunk diameter by $1.3 \mathrm{~m}$ in two mutually perpendicular directions; selection category; Kraft's growth class; tree condition; presence of defects and damage; bark type, belonging to certain phenological forms, presence of flowering, fruiting. Taxational indicators of growing stock were calculated using standard methods [44]. During the survey of forest stands, the scale of selection categories was used, which represents a modification of the Veresin scale [38].

Test areas were laid in the most typical part of the plantation. In the case when the object included allocations that differ significantly from each other (if the species composition in the composition of the plantation differs by 2 units or more, stand density by 0.2 or more, quality class by 2 classes or more, age of the stand by 30 years or more, etc.), two test areas were laid [44]. Forest stands (quarter, compartment) were selected based on the latest forest management materials available in the forestry (forestry enterprise), and a reconnaissance survey of the entire object, which was carried out simultaneously with the survey of its external borders. A complete list of all trees on test areas (TA) with a diameter of more than $8 \mathrm{~cm}$ was made to measure their diameters and determine whether they belong to the first or second (third) storeys. For trees of the $1^{\text {st }}$ storey, the Kraft's growth class, selection category, and general tree condition were determined. The average height was determined using a standard taxation method: measuring 15-25 trees in proportion to their number in each degree of thickness; plotting a height curve. Diameters were measured with an accuracy up to $1 \mathrm{~cm}$, heights - up to $1 \mathrm{~m}$.

Assessment of technological processes of timber logging and its impact on the components of forest 
phytocenoses within the enterprise was carried out based on the existing technological maps and field surveys of areas with existing logging operations. Assessment of natural regeneration was carried out based on a preliminary analysis of taxation materials and temporary test areas, which are laid down according to conventional methods in forest taxation [44].

\section{RESULTS AND DISCUSSION}

Forestry and ecological characteristics of the research object

According to forest-type zoning, the territory of the forestry belongs to the forest-steppe zone and to the Dniester-Dnieper forest-economic district. It is a part of the Central Podolsk Forest-Economic district, which is characterised by the presence of forest strips and massifs on water sections and separate tracts among steppe plots. It is characterised by unstable, variable soil moisture, wide distribution of grey podzolic soils and chernozems, mixed composition of flora and fauna. The stands belong to mixed deciduous forests [7].

The climate in the forestry area is temperate continental with sufficient precipitation. Among the climatic factors that negatively affect the growth and development of woody vegetation, the following can be noted: variable soil moisture, periodic droughts and dry winds; heavy precipitation that repeats every $5-10$ years, early autumn and late spring frosts; snowless winter periods in the presence of frosts [9]. Information on the distribution of natural oak stands by forest type is shown in Figure 1.

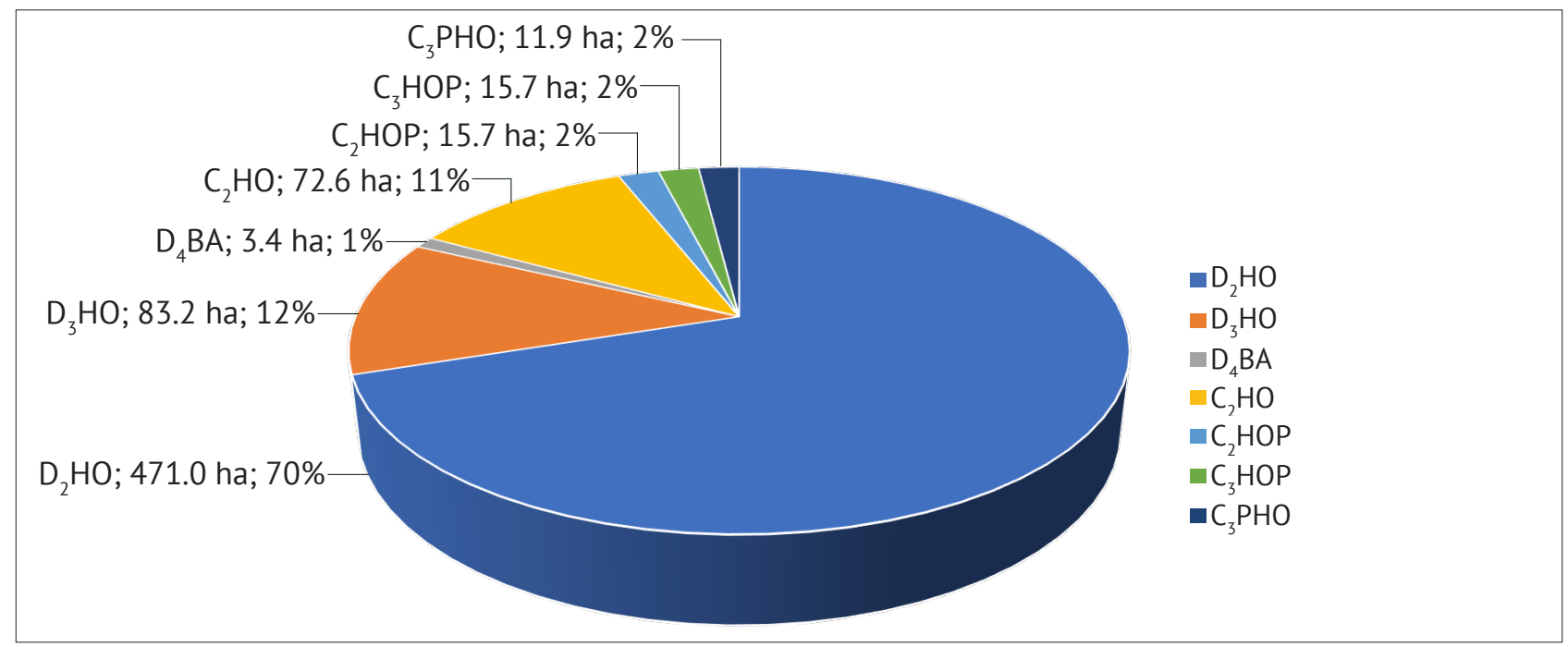

Figure 1. Forest type localisation of natural oak stands in SE "Khmilnytske lisove hospodarstvo" Source: mensurational descriptions of SE "Khmilnytske lisove hospodarstvo"

According to Figure 1 natural oak forests of the enterprise are concentrated in 7 forest types. The largest areas of stands are represented by fresh hornbeam oak forest - 471 hectares (70\%). 83.2 hectares of plantings (12\%) are concentrated in the wet hornbeam oak forest. Slightly smaller areas - 72.6 hectares (11\%) - are stands of fresh hornbeam sudubrava. Information about the origin of natural oak stands is shown in Figure 2.

According to Figure 2 within the enterprise, natural oak stands mainly of vegetative origin predominate. The area of such stands is 528.6 hectares (78\%). The area of stands of seed origin is 148.9 hectares (22\%).

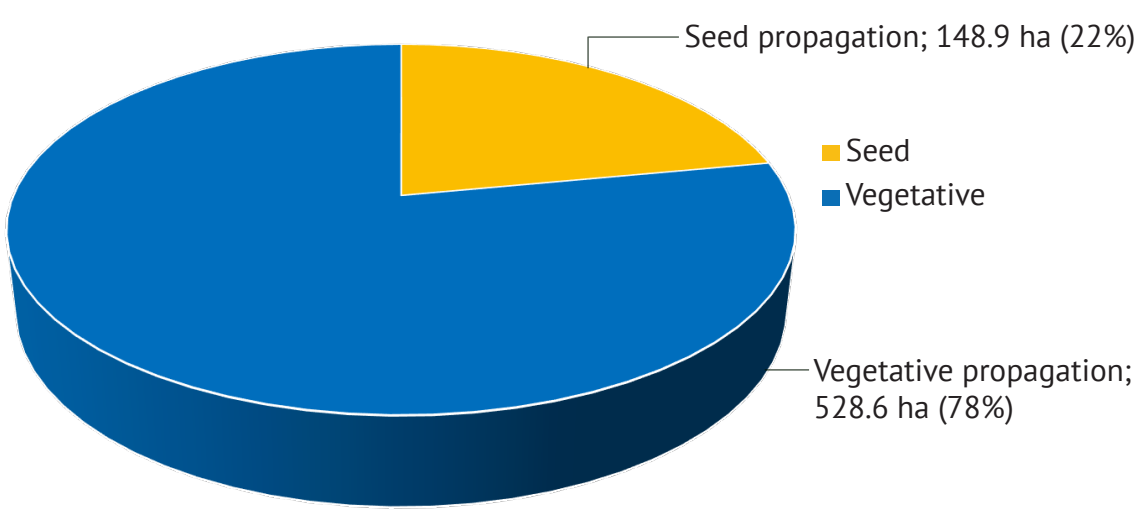

Figure 2. Origin of natural oak forests in SE "Khmilnytske lisove hospodarstvo" Source: mensurational descriptions of SE "Khmilnytske lisove hospodarstvo" 
Taxational specifications of natural oak forests of SE "Khmilnytske lisove hospodarstvo"

Preserving biological and genetic diversity is one of the main and most important functions of natural oak forests. Old-aged forests are particularly important for preserving biodiversity. The study analysed the presence of sites of old-aged forests in the conditions of the enterprise. The data is shown in Table 1. Plots of stands aged 120 years or more are located in the
Kozyatynske, Bereznyanske, and Litynske forestry departments. The total number of such land plots is 20 . The total area of stands over 120 years old and over 4.0 hectares is 297.8 hectares. These are forest stands are mainly represented by common oak (Co) with European hornbeam (Eh), small-leaved linden (Sll), European ash (Ea), Norway maple (Nm). The surveyed stands also include Scots pine (Sp), Norway spruce (Ns), white birch $(\mathrm{Wb})$, black adler $(\mathrm{Ba})$, Dutch beech $(\mathrm{Db})$.

Table 1. Taxational specifications of plots older than 120 years, with an area of more than 4 hectares within the enterprise

\begin{tabular}{|c|c|c|c|c|c|c|c|c|c|}
\hline Sq/species & Area, ha & Plant composition & $\begin{array}{l}\text { Age, } \\
\text { years }\end{array}$ & Height, m & $\begin{array}{l}\text { Diameter, } \\
\mathrm{cm}\end{array}$ & $\begin{array}{l}\text { Quality } \\
\text { class }\end{array}$ & Density & $\begin{array}{c}\text { Forest } \\
\text { site type }\end{array}$ & $\begin{array}{c}\text { Stand } \\
\text { volume } \\
\text { per } 1 \text { ha, } \\
\mathrm{m}^{3}\end{array}$ \\
\hline \multicolumn{10}{|c|}{ Kozyatynske forestry department } \\
\hline $16 / 6$ & 12.5 & 8Co1Eh1Ea & 121 & 27 & 48 & 2 & 0.60 & $\mathrm{D}_{2}-\mathrm{hO}$ & 280 \\
\hline $16 / 9$ & 14.5 & 9Co1Ea & 121 & 28 & 44 & 2 & 0.70 & $\mathrm{D}_{2}-\mathrm{hO}$ & 330 \\
\hline $17 / 10$ & 4.8 & $10 \mathrm{Co}+\mathrm{Bc}+\mathrm{Eh}$ & 121 & 27 & 48 & 2 & 0.55 & $\mathrm{D}_{2}-\mathrm{hO}$ & 260 \\
\hline $19 / 5$ & 14.0 & $10 \mathrm{Co}+\mathrm{Eh}+\mathrm{Nm}$ & 126 & 28 & 48 & 2 & 0.60 & $\mathrm{D}_{2}-\mathrm{hO}$ & 280 \\
\hline $22 / 2$ & 9.0 & $10 \mathrm{Co}+\mathrm{Nm}+\mathrm{Eh}$ & 126 & 28 & 48 & 2 & 0.70 & $\mathrm{D}_{2}-\mathrm{hO}$ & 300 \\
\hline $23 / 7$ & 15.0 & $9 \mathrm{Co} 1 \mathrm{Nm}+\mathrm{Eh}$ & 121 & 27 & 48 & 2 & 0.70 & $\mathrm{D}_{2}-\mathrm{hO}$ & 300 \\
\hline $23 / 10$ & 5.6 & $10 \mathrm{Co}+\mathrm{Ea}+\mathrm{Nm}$ & 121 & 27 & 48 & 2 & 0.50 & $\mathrm{D}_{2}-\mathrm{hO}$ & 230 \\
\hline $24 / 1$ & 7.3 & $9 \mathrm{Co} 1 \mathrm{Nm}+\mathrm{Eh}$ & 121 & 27 & 48 & 2 & 0.60 & $\mathrm{D}_{2}-\mathrm{hO}$ & 260 \\
\hline $24 / 3$ & 16.0 & $10 \mathrm{Co}+\mathrm{Eh}+\mathrm{Nm}$ & 121 & 27 & 48 & 2 & 0.50 & $\mathrm{D}_{2}-\mathrm{hO}$ & 230 \\
\hline Total & 98.7 & - & 122 & 27 & 48 & 2 & 0.60 & - & 274 \\
\hline \multicolumn{10}{|c|}{ Bereznyanske forestry department } \\
\hline $19 / 1$ & 4.4 & 6Co2Eh2Eh & 126 & 28 & 48 & 2 & 0.55 & $\mathrm{D}_{2}-\mathrm{hO}$ & 190 \\
\hline Total & 4.4 & - & 126 & 28 & 48 & 2 & 0.55 & - & 190 \\
\hline \multicolumn{10}{|c|}{ Litynske forestry department } \\
\hline $18 / 4$ & 22.0 & $10 \mathrm{Co}+\mathrm{SIl}+\mathrm{Eh}$ & 121 & 30 & 44 & 1 & 0.60 & $\mathrm{D}_{2}-\mathrm{hO}$ & 330 \\
\hline $18 / 12$ & 4.2 & 6Co4Eh & 136 & 30 & 48 & 2 & 0.70 & $\mathrm{D}_{2}-\mathrm{hO}$ & 320 \\
\hline $23 / 1$ & 29.0 & $10 \mathrm{Co}+\mathrm{SIl}+\mathrm{Eh}$ & 146 & 30 & 48 & 2 & 0.50 & $\mathrm{D}_{2}-\mathrm{hO}$ & 240 \\
\hline $26 / 3$ & 8.8 & 7Co2SIl1Eh & 126 & 30 & 48 & 2 & 0.70 & $\mathrm{D}_{2}-\mathrm{hO}$ & 350 \\
\hline $42 / 2$ & 37.4 & 4Co5Eh1SIl & 121 & 30 & 44 & 2 & 0.65 & $\mathrm{D}_{2}-\mathrm{hO}$ & 320 \\
\hline $52 / 4$ & 12.7 & 5Co3Sll1Eh+Nm & 126 & 28 & 44 & 2 & 0.60 & $\mathrm{D}_{2}-\mathrm{hO}$ & 290 \\
\hline $53 / 2$ & 33.0 & 4Co5SIl1Eh+Nm & 126 & 30 & 40 & 1 & 0.70 & $\mathrm{D}_{2}-\mathrm{hO}$ & 360 \\
\hline $53 / 5$ & 11.0 & 6Co3SIl1Eh & 126 & 30 & 40 & 2 & 0.60 & $\mathrm{D}_{2}-\mathrm{hO}$ & 320 \\
\hline $54 / 9$ & 14.2 & $6 \mathrm{Co} 2 \mathrm{SIL} 2 \mathrm{Eh}$ & 121 & 28 & 40 & 2 & 0.60 & $\mathrm{D}_{2}-\mathrm{hO}$ & 280 \\
\hline $54 / 14$ & 23.3 & $6 \mathrm{Co} 2 \mathrm{SII} 2 \mathrm{Eh}$ & 121 & 28 & 40 & 2 & 0.70 & $\mathrm{D}_{2}-\mathrm{hO}$ & 350 \\
\hline Total & 195.6 & - & 127 & 29 & 44 & 1.8 & 0.63 & & 316 \\
\hline $\begin{array}{l}\text { Total for } \\
\text { enterprise }\end{array}$ & 298.7 & - & 125 & 28 & 46 & 1.9 & 0.62 & $\mathrm{O}_{2} \mathrm{HO}$ & 291 \\
\hline
\end{tabular}

Source: mensurational descriptions of SE "Khmilnytske lisove hospodarstvo" 
The distribution of stands by age class in the enterprise is shown in Table 2.

According to the table, the largest area of plantings of the $11^{\text {th }}$ age class is 188.0 hectares. A significant area of stands of the $8^{\text {th }}$ age class is also 107.5 hectares. The smallest areas are occupied by natural oak stands of the $4^{\text {th }}$ age class -4.8 hectares. Despite the significant areas of forest stands of the $8^{\text {th }}$ age class, a minimum proportion of oak is observed -2 units. The largest proportion of oak is present in stands of the $12^{\text {th }}$ and $14^{\text {th }}$ age classes (9-10 units).

The enterprise's natural oak forests are mostly high-bonitat (the $1^{\text {st }}$ quality class prevails). Mature and over-mature stands have slightly lower productivity $\left(2^{\text {nd }}\right.$ quality class). The predominant stand density - 0.6-0.7. Mature and over-mature stands are characterised by a decrease in average density to $0.5-0.6$. The lowest density of natural oak stands of the $14^{\text {th }}$ age class -0.5 .

The largest total reserve is characterised by stands of the $11^{\text {th }}$ age class. This is conditioned by their large area and fairly high productivity. The maximum average stand volume of the $9^{\text {th }}$ age class $-290 \mathrm{~m}^{3} / \mathrm{ha}$. Naturally, the smallest stand volume was found in plantings of the $4^{\text {th }}$ age class $\left(105 \mathrm{~m}^{3} / \mathrm{ha}\right)$. Natural forest stands are characterised by a significant decrease in average stand volume starting from the $10^{\text {th }}$ age class. The average growth rate $-1.7-3.9 \mathrm{~m}^{3} / \mathrm{ha}$. The lowest increment in mature and over-mature stands $-1.7-2.0 \mathrm{~m}^{3} / \mathrm{ha}$. The peak increment is observed in the $7^{\text {th }}$ age class $3.9 \mathrm{~m}^{3} / \mathrm{ha}$.

Data on the distribution of stocks of modal and optimal stands are presented in Figure 3.

Table 2. Distribution of natural oak stands by age classes in the conditions of SE "Khmilnytske lisove hospodarstvo"

\begin{tabular}{cccccccc}
\hline Age classes & $\begin{array}{c}\text { Average stand } \\
\text { composition }\end{array}$ & Area, ha & $\begin{array}{c}\text { Average } \\
\text { quality class }\end{array}$ & $\begin{array}{c}\text { Average } \\
\text { stand } \\
\text { density }\end{array}$ & $\begin{array}{c}\text { Total stand } \\
\text { volume, } \mathbf{m}^{3}\end{array}$ & $\begin{array}{c}\text { Average } \\
\text { stand volume } \\
\mathbf{m}^{3} / \mathbf{h a}\end{array}$ & $\begin{array}{c}\text { Mean } \\
\text { increment, } \\
\mathbf{m}^{3} / \mathbf{h a}\end{array}$ \\
\hline 4 & 6Sll2Co1Nm1Ea & 4.8 & 1.0 & 0.70 & 504.0 & 105.0 & 3.0 \\
\hline 5 & 4Sp3Ns1Co1Eh1Wb & 25.8 & 1.0 & 0.66 & 3922 & 152.6 & 3.4 \\
\hline 6 & 4Ns3Sp2Co1Eh & 38.9 & 1.1 & 0.68 & 10114.0 & 260.0 & 4.7 \\
\hline 7 & 4Co2Eh1Db2Nm1Bc & 89.7 & 1.5 & 0.67 & 23124.6 & 257.8 & 3.9 \\
\hline 8 & 2Ea2Co2Eh1Nm1Sp1Wb & 107.5 & 1.2 & 0.61 & 29068.0 & 270.4 & 3.6 \\
\hline 9 & 4Co4Eh2Ea & 43.4 & 1.6 & 0.63 & 12586.0 & 290.0 & 3.4 \\
\hline 10 & 5Co2Ea2Eh1Nm & 87.3 & 1.9 & 0.63 & 23745.6 & 272.0 & 2.8 \\
\hline 11 & 7Co2Ea1Eh & 188.0 & 2.3 & 0.62 & 45872.0 & 244.0 & 2.3 \\
\hline 12 & 9Co1Nm+Eh & 59.1 & 2.0 & 0.53 & 14249.0 & 241.1 & 2.0 \\
\hline 14 & 10Co+Eh+Nm & 29.0 & 2.0 & 0.50 & 6960.0 & 240.0 & 1.7 \\
\hline
\end{tabular}

Source: mensurational descriptions of SE "Khmilnytske lisove hospodarstvo"

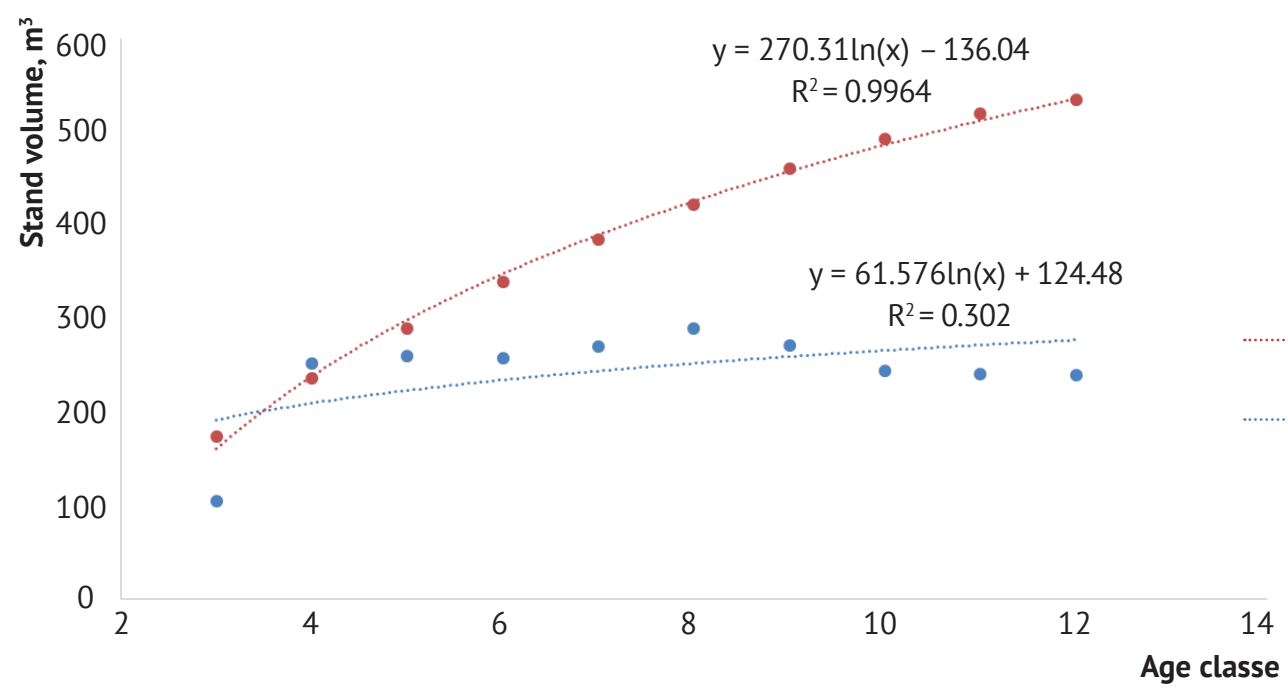

Figure 3. Dynamics of modal and optimal reserves of natural oak forest stands of SE "Khmilnytske lisove hospodarstvo" Source: mensurational descriptions of SE "Khmilnytske lisove hospodarstvo" 
According to Figure 3 starting from the $4^{\text {th }}$ age class, there is a significant decrease in modal reserves compared to optimal ones. With increasing age, this difference increases significantly. Data on the distribution of stands by the share of oak in the stand composition are shown in Table 3.

According to the table, the greatest share of oak in the stand composition (9-10 units) is characteristic for stands of 9-10 age classes. The lowest share of oak was observed in stands of 80 years of age. In these stands, the share of oak can be reduced to 1-2 units. Table 4 shows the distribution of natural stands by density in the conditions of the enterprise.

Table 3. Distribution of plantings by share of natural oak in the stand composition in the conditions of the SE "Khmilnytske lisove hospodarstvo"

\begin{tabular}{cccccccc}
\hline $\begin{array}{c}\text { Share of } \\
\text { oak in stand } \\
\text { composition } \\
\text { (units) }\end{array}$ & $\begin{array}{c}\text { Average age } \\
\text { of plantings }\end{array}$ & Area, ha & $\begin{array}{c}\text { Average } \\
\text { quality class }\end{array}$ & $\begin{array}{c}\text { Average stand } \\
\text { density }\end{array}$ & $\begin{array}{c}\text { Total stand } \\
\text { volume }\end{array}$ & $\begin{array}{c}\text { Average stand } \\
\text { vol-ume per } \\
\text { hectare }\end{array}$ & $\begin{array}{c}\text { Mean } \\
\text { increment, } \\
\mathbf{m}^{3} / \text { ha }\end{array}$ \\
\hline $9-10$ & 100 & 178.0 & 2.1 & 0.63 & 44215 & 248.4 & 2.4 \\
\hline $7-8$ & 82 & 53.1 & 2.0 & 0.62 & 12553 & 236.4 & 2.8 \\
\hline $6-5$ & 76 & 52.5 & 2.0 & 0.65 & 13556 & 258.2 & 3.3 \\
\hline $4-3$ & 86 & 102.1 & 1.9 & 0.65 & 27332 & 267.7 & 3.1 \\
\hline $2-1$ & 82 & 287.8 & 2.0 & 0.61 & 66827 & 232.2 & 2.8 \\
\hline Total/average & 85 & 673.5 & 2.0 & 0.63 & 164483 & 248.6 & 2.9 \\
\hline
\end{tabular}

Source: mensurational descriptions of SE "Khmilnytske lisove hospodarstvo"

Table 4. Distribution of oak stands of natural origin by completeness in the conditions of SE "Khmilnytske lisove hospodarstvo"

\begin{tabular}{cccccccc} 
Stand density & Average stand composition & $\begin{array}{c}\text { Average age } \\
\text { of stand }\end{array}$ & Area, ha & $\begin{array}{c}\text { Average } \\
\text { quality class }\end{array}$ & $\begin{array}{c}\text { Total stand } \\
\text { volume, } \mathrm{m}^{3}\end{array}$ & $\begin{array}{c}\text { Average stand } \\
\text { volume per ha } \\
\mathrm{m}^{3} / \mathrm{ha}^{2}\end{array}$ & $\begin{array}{c}\text { Mean } \\
\text { increment, } \\
\mathrm{m}^{3} / \mathrm{ha}\end{array}$ \\
\hline $0.3-0.4$ & 5Co2Ns2Sp1Ea & 113 & 2.4 & 2 & 20712.9 & 183.3 & 1.6 \\
\hline $0.5-0.6$ & 4Co3Ea2Ec1Nm & 82 & 205.9 & 1.7 & 19852.2 & 242.1 & 2.9 \\
\hline $0.7-0.8$ & 4Co1Ea1Ec1Nm1SIISp1Ns & 70 & 272.9 & 1.8 & 19131.0 & 273.3 & 3.9 \\
\hline $0.9-1.0$ & 3Ea2Co2Eh1Nm1Ba1Db & 32 & 2.2 & 1.5 & 4640.0 & 145.0 & 4.5 \\
\hline
\end{tabular}

Source: mensurational descriptions of SE "Khmilnytske lisove hospodarstvo"

According to the above data, the low-density oak stands are mostly of old. The average age of such stands is 113 years. Along with this, their area is insignificant and is only 2.4 hectares. The area of high-density oak stands is also insignificant and amounts to only 2.2 hectares. The largest area is represented by stands with a density of $0.7-0.8$. These stands are mostly 70 years old. Significant areas of oak forest are represented by stands with density of 0.5-0.6 - 205.9 ha, which are mostly 80 years old.

Data on the distribution of stands by quality class are shown in Table 5.

According to Table 5, stands of 1-2 quality classes predominate. The area of natural oak forests of 1-2 quality classes -640.4 hectares. Low-bonitat plantings (3-4 quality classes) cover an area of only 33.1 hectares.

Table 5. Distribution of natural oak stands by quality class in the conditions of SE "Khmilnytske lisove hospodarstvo"

\begin{tabular}{ccccccc}
\hline Quality class & Average stand composition & $\begin{array}{c}\text { Average age } \\
\text { of stand }\end{array}$ & Area, ha & $\begin{array}{c}\text { Average stand } \\
\text { density }\end{array}$ & $\begin{array}{c}\text { Average stand } \\
\text { volume per ha } \\
\mathbf{m}^{3} / \mathbf{h a}\end{array}$ & $\begin{array}{c}\text { Mean } \\
\text { increment, } \\
\mathbf{m}^{3} / \mathbf{h a}\end{array}$ \\
\hline I-II & 4Co2Ea1Ec1Nm1Sp1Ns & 73 & 640.4 & 0.65 & 260.5 & 3.5 \\
\hline III-IV & 9Co1Eh & 108 & 33.1 & 0.58 & 214.3 & 1.98 \\
\hline
\end{tabular}

Source: mensurational descriptions of SE "Khmilnytske lisove hospodarstvo" 
Reforestation processes in the enterprise environment Technological processes of timber logging within the enterprise include: felling trees manually, without the use of machines; pruning branches, unloading for sorting; skidding sorting by wheeled tractors with jaw grippers; loading and removal of sorting and wood by cars. Cutting areas with viable undergrowth that provides reforestation, as well as cutting areas designed for growth renewal, are developed mainly from October 1 to April 1, which ensures its maximum preservation.

The surveyed areas of complete cutting indicate the predominance of artificial reforestation. Along with this, for the creation of forest crops, natural regeneration of the forest is used, in particular, common oak, if any, is available on the plots. In stands with a predominance of oak, areas with existing undergrowth are noted. The undergrowth of common oak is mainly concentrated in fresh and moist hornbeam sudubravas (Table 6).

Table 6. Taxational specifications of natural oak stands with the existing oak undergrowth

\begin{tabular}{|c|c|c|c|c|c|c|c|c|c|c|c|c|}
\hline \multirow{2}{*}{ 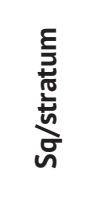 } & \multirow{2}{*}{ 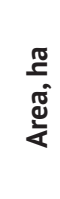 } & \multirow{2}{*}{ 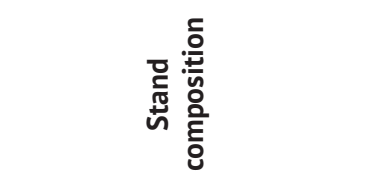 } & \multirow{2}{*}{ 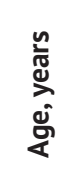 } & \multirow{2}{*}{ 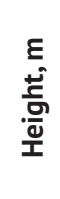 } & \multirow{2}{*}{ 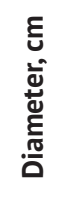 } & \multirow{2}{*}{ 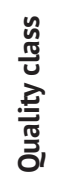 } & \multirow{2}{*}{ 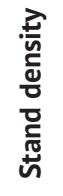 } & \multirow{2}{*}{ 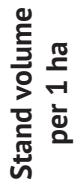 } & \multirow{2}{*}{ 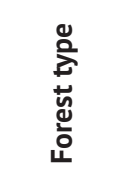 } & \multicolumn{3}{|c|}{ Undergrowth } \\
\hline & & & & & & & & & & $\begin{array}{l}\text { D } \\
\text { 㐏 } \\
\text { जे }\end{array}$ & 莲 & 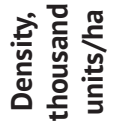 \\
\hline \multicolumn{13}{|c|}{ Kozyatynske forestry department } \\
\hline $28 / 1$ & 2.3 & 5Sp4Ns1Co & 74 & 28 & 36 & $1 \mathrm{~A}$ & 0.6 & 400 & $\mathrm{C}_{2}-\mathrm{h}-\mathrm{oP}$ & $8 \mathrm{Eh} 2 \mathrm{Co}$ & 15 & 2.0 \\
\hline $28 / 13$ & 1.8 & $9 \mathrm{~Wb} 1 \mathrm{Co}+\mathrm{TC}+\mathrm{Db}$ & 50 & 21 & 22 & $1 \mathrm{~A}$ & 0.6 & 160 & $C_{3}-h-o P$ & $10 \mathrm{Co}$ & 15 & 1.0 \\
\hline $38 / 9$ & 1.7 & 9Sp1Co & 49 & 21 & 22 & $1 \mathrm{~A}$ & 0.7 & 330 & $C_{2}-h-o P$ & $10 \mathrm{Co}$ & 15 & 1.0 \\
\hline $38 / 11$ & 1.4 & 9Sp1Co & 51 & 21 & 22 & $1 \mathrm{~A}$ & 0.7 & 320 & $\mathrm{C}_{2}-\mathrm{h}-\mathrm{O}$ & $10 \mathrm{Co}$ & 10 & 2.0 \\
\hline $29 / 7$ & 1.0 & $10 \mathrm{Co}+\mathrm{Wb}$ & 105 & 23 & 32 & 3 & 0.7 & 250 & $\mathrm{C}_{2}-\mathrm{h}-\mathrm{O}$ & 4Eh2Co2Bc2SIl & 20 & 3.0 \\
\hline $29 / 13$ & 1.8 & $10 \mathrm{Co}+\mathrm{Wb}$ & 105 & 23 & 32 & 3 & 0.5 & 180 & $C_{2}-h-O$ & 4Eh2Co2Bc2SIl & 20 & 3.0 \\
\hline $29 / 14$ & 1.3 & $10 \mathrm{Co}+\mathrm{Wb}$ & 105 & 23 & 32 & 3 & 0.7 & 250 & $\mathrm{C}_{2}-\mathrm{h}-\mathrm{O}$ & 4Eh2Co2Bc2SIl & 20 & 3.0 \\
\hline \multicolumn{13}{|c|}{ Shyrokogrebelske forestry rebartment (cutting) } \\
\hline $58 / 5$ & 0.6 & $5 \mathrm{Ba} 2 \mathrm{Co} 2 \mathrm{Eh} 1 \mathrm{Nm}+\mathrm{Sll}+\mathrm{BP}+\mathrm{Db}$ & 6 & 2 & 2 & 1 & 0.7 & 5 & $\mathrm{D}_{4} \mathrm{Ba}$ & 5Eh2Co1Nm1Wb1Sll & 10 & 1.0 \\
\hline
\end{tabular}

Source: field materials (materials of temporary test areas)

According to Table 6, the natural regeneration of common oak is mainly concentrated in fresh sudubravas. Of the 8 surveyed plots, 6 are represented by fresh hornbeam sudubrava. Other areas are localised in wet hornbeam sudubrava and wet black poplar grud. The density of young growth is 1-3 thousand units/ha. This is mainly a undergrowth of $10-20$ years of age with a composition of oak of 2-10 units.

\section{CONCLUSIONS}

The structure of natural oak forests is dominated by forest stands of vegetative origin (528.6 ha, or 78\%). Forest stands aged 120 years or more are located in the Kozyatynske, Bereznyanske, and Litynske forestry departments. The total area of such stands -297.8 hectares. The greatest share of oak in the stand composition (910 units) is typical for plantings of 9-10 age classes. The lowest share of oak was observed in stands of 80 years of age. In these stands, the share of oak can be reduced to 1-2 units. According to the table, the largest area of stands of the $11^{\text {th }}$ age class -188.0 ha. A significant area is occupied by stands of the $8^{\text {th }}$ age class -107.5 ha.

The enterprise's natural oak forests are mostly high-bonitat (the $1^{\text {st }}$ quality class prevails). Mature and over-mature stands have slightly lower productivity ( $2^{\text {nd }}$ quality class). The predominant stand density $-0.6-$ 0.7 . Mature and over-mature stands are defined by a decrease in the average density to 0.5-0.6; the lowest density of natural oak stands of the $14^{\text {th }}$ age class -0.5 . The maximum average stand volume of the $9^{\text {th }}$ age class $-290 \mathrm{~m}^{3} / \mathrm{ha}$. Naturally, the smallest stand volume was found in plantings of the $4^{\text {th }}$ age class $\left(105 \mathrm{~m}^{3} / \mathrm{ha}\right)$. Natural forest stands are characterised by a significant decrease in average stand volume starting from the $10^{\text {th }}$ age class. The mean increment rate $-1.7-3.9 \mathrm{~m}^{3} / \mathrm{ha}$. The lowest increment in mature and over-mature stands $-1.7-2.0 \mathrm{~m}^{3} / \mathrm{ha}$. The peak increment is observed in the $7^{\text {th }}$ age class $-3.9 \mathrm{~m}^{3} / \mathrm{ha}$.

In stands with a predominance of oak, areas with existing undergrowth are noted. The undergrowth of common oak is mainly concentrated in fresh and moist hornbeam sudubravas (Table 6). The density of young growth is 1-3 thousand units/ha. This is mainly an undergrowth of 10-20 years, both with a predominance and a share of 2-3 oak units. 


\section{REFERENCES}

[1] Savill,P.(2013). The silviculture of trees used in British forestry (2nd ed.). Wallingford, Oxfordshire: CABI Publishing.

[2] Smit, C., Kuijper, D.P.., Prentice, D., Wassen, M.J., \& Cromsigt, J.P.G.M. (2012). Coarse woody debris facilitates oak recruitment in Białowieża Primeval Forest, Poland. Forest Ecology and Management, 284, 133-141.

[3] Götmark, F., Schott, K.M., \& Jensen, A.M. (2011). Factors influencing presence-absence of oak (Quercus spp.) seedlings after conservation-oriented partial cutting of high forests in Sweden. Scandinavian Journal of Forest Research, 26(2), 136-145.

[4] Lorimer, C.G., Chapman, J.W., \& Lambert, W.D. (1994). Tall understorey vegetation as a factor in the poor development of oak seedlings beneath mature stands. Journal of Ecology, 82(2), 227-237.

[5] Schmidt, K.A. (2003). Linking frequencies of acorn masting in temperate forests to long-term population growth rates in a songbird: The veery (Catharus fuscescens). Oikos, 103(3), 548-558.

[6] Johnson, P.S., Shifley, S.R., \& Rogers, R. (2002). The ecology and silviculture of oaks. Wallingford, Oxfordshire: CABI Publishing.

[7] Vera, F.W.M. (2000). Grazing ecology and forest history. Wallingford, Oxfordshire: CABI Publishing.

[8] Bruun, H.H., Paltto, H., Nordberg, A., Nordén, B., \& Snäll, T. (2011). Development of secondary woodland in oak wood pastures reduces the richness of rare epiphytic lichens. PLOS ONE, 6(9), article number e24675.

[9] Ranius, T., Niklasson, M., \& Berg, N. (2009). Development of tree hollows in pedunculate oak (Quercus robur). Forest Ecology and Management, 257(1), 303-310.

[10] Leonardsson, J. (2015). Skötsel av ekblandskogar: Naturvårdsgallring och respons hos träd och buskar. Diss. Gothenburg: University of Gothenburg.

[11] Sandström, J., Bjelke, U., Carlberg, T., \& Sundberg, S. (2015). Tillstånd och trender för arter och deras livsmiljöerrödlistade arter $i$ Sverige 2015. ArtDatabanken Rapporterar, 17. Retrieved from https://pub.epsilon.slu. se/12443/1/sandstrom___etal_150819.pdf

[12] Bobiec, A., Jaszcz, E., \& Wojtunik, K. (2011). Oak (Quercus robur L.) regeneration as a response to natural dynamics of stands in European hemiboreal zone. European Journal of Forest Research, 130(5), 785-797.

[13] Götmark, F., \& Kiffer, C. (2014). Regeneration of oaks (Quercus robur / Q. petraea) and three other tree species during long-term succession after catastrophic disturbance (windthrow). Plant Ecology, 215(9), 1067-1080.

[14] Zhukov, A.B. (1949). Dubravy of the Ukrainian SSR and methods of their restoration (Vol. 1). Moscow: Goslesbumizdat.

[15] Ivanitskiy, R.S. (2011). Natural regeneration of tree stands at the logs of the Surazky forest dacha. Scientific Bulletin of NLTU of Ukraine, 21(10), 19-24.

[16] Annighoefer, P., Beckschaefer, P., Vor, T., \& Ammer, C. (2015). Regeneration patterns of European oak species (Quercus petraea (Matt.) Liebl., Quercus robur L.) in dependence of environment and neighborhood. PLoS ONE, 10(8), article number e0134935.

[17] Kuehne, C., Nosko, P., Horwath, T., \& Bauhus, J. (2014). A comparative study of physiological and morphological seedling traits associated with shade tolerance in introduced red oak (Quercus rubra) and native hardwood tree species in southwestern Germany. Tree Physiology, 34(2), 184-193.

[18] Götmark, F., \& Kiffer, C. (2014). Regeneration of oaks (Quercus robur/Q. petraea) and three other tree species during long-term succession after catastrophic disturbance (windthrow). Plant Ecology, 215(9), 1067-1080.

[19] Löf, M., Møller-Madsen, E., \& Rytter, L. (2009). Skötsel av ädellövskog. Skogsstyrelsen, Jönköping. Skogsskötselserien, nr 10. Retrieved from https://www.skogsstyrelsen.se/globalassets/mer-om-skog/skogsskotselserien/skogsskotselserien-10-skotsel-av-adellovskog.pdf.

[20] Wolf, A., Møller, P.F., Bradshaw, R.H.W., \& Bigler, J. (2004). Storm damage and long-term mortality in a seminatural, temperate deciduous forest. Forest Ecology and Management, 188(1-3), 197-210.

[21] Ligot, G., Balandier, P., Fayolle, A., Lejeune, P., \& Claessens, H. (2013). Height competition between Quercus petraea and Fagus sylvatica natural regeneration in mixed and uneven-aged stands. Forest Ecology and Management, 304, 391-398.

[22] Ziegenhagen, B., \& Kausch, W. (1995). Productivity of young shaded oaks (Quercus robur L.) as corresponding to shoot morphology and leaf anatomy. Forest Ecology and Management, 72(2-3), 97-108.

[23] Aldrich, P.R., Parker, G.R., Ward, J.S., \& Michler, C.H. (2003). Spatial dispersion of trees in an old-growth temperate hardwood forest over 60 years of succession. Forest Ecology and Management, 180(1-3), 475-491.

[24] McCormick, J.F., \& Platt, R.B. (1980). Recovery of an appalachian forest following the chestnut blight or Keever, Catherine - you were right. American Midland Naturalist, 104(2), 264-273.

[25] Sustainable Forestry Initiative (2010-2014) Standard. (n.d.). Retrieved from http://www.sfiprogram.org/files/ pdf/section2sfirequirements2010-2014pdf/.

[26] Resolution H1: General Guidelines for the Sustainable Management of Forests in Europe. (1993). Retrieved from https://www.foresteurope.org/docs/MC/MC_helsinki_resolutionH1.pdf.

[27] Resolution H2: General Guidelines for the Conservation of the Biodiversity of European Forests. (1993). Retrieved from https://www.foresteurope.org/docs/MC/MC_helsinki_resolutionH2.pdf.

[28] Kravets, P.V., \& Lakyda, P.I. (2002). Criteria and indicators of new forest management. Scientific Bulletin of UNFU, 12(7), 146-158.

[29] Lavrov, V.V., \& Furdichko, O.I. (2009). Forestry industry of Ukraine in the context of sustainable development: Theoretical and methodological, regulatory and legal aspects. Kyiv: Osnova. 
[30] Furdychko, O.I. (2003). Forestry of Ukraine: Perspectives, criteria and indicators of environmentally sustainable management and conducting. Regional Economy, 2, 21-35.

[31] Furdychko, O.I., Shershun, M.Kh., \& Neyko, I.S. (2012). The basic principles of systematization and optimization of criteria and indicators of the pan-European strategy of sustainable forest management. Taurian Scientific Bulletin, 71, 362-370.

[32] Volosyanchuk, R., Prots, B., \& Kagalo, A. (Eds.). (2017). Criteria and methodology for virgin and old growth (quasivirgin) forests identification. Lviv: Liga-Press.

[33] Ostapenko, B.F., \& Tkach, V.P. (2002). Forest typology (Part 2). Kharkiv: Maidan.

[34] Krinitskiy,H.T., \& Chernyavskiy,M.V.(2015). Close to nature forest management is the basis of forest management in the Carpathian region (experience of Ukraine and Slovakia). Forestry and Forest Melioration, 126, 52-59.

[35] Didenko, M.M. (2008). Peculiarities of the natural regeneration of oak stands of the fresh maple-lime forest types. Bulletin of Kharkiv National Agrarian University, 4, 112-114.

[36] Didenko, M.M. (2008). Condition of the natural oak regeneration under canopy of parent forest stands. Forestry and Forest Melioration, 113, 186-190.

[37] Ischuk, H.P. (2017). Natural regeneration of oak and hornbeam under the canopy and log cabins in the State Enterprise “Korsun-Shevchenko Forestry". Scientific Bulletin of UNFU, 27(1), 15-18.

[38] Bilous, V.I. (2004). Tree breeding and seed production of oak. Cherkasy: HIITEXIM.

[39] Bobiec, A., Kuijper, D.P.J., Niklasson, M., Romankiewicz, A., \& Solecka, K. (2011). Oak (Quercus robur L.) regeneration in early successional woodlands grazed by wild ungulates in the absence of livestock. Forest Ecology and Management, 262(5), 780-790.

[40] Kharchenko, H.A., \& Kharchenko, H.H. (2012). To the question of natural regeneration of pedunculate oak under the canopy of the parent stand. Scientific Journal of KubSAU, 76(02), 299-311.

[41] Tkach, V.P., \& Holovach, R.V. (2010). Current state of the natural oak forest stands of the Left-bank Forest Steppe of Ukraine. Forestry and Forest Melioration, 116, 79-84.

[42] Vasylevsky, O.H., Neyko, I.S., Elisavenko, Yu.A., \& Matusyak, M.V. (2018). Characteristics of the structure and forest regeneration processes of natural oak woodlands of SE "Kryzhopilske LG". Scientific Bulletin of VNAU,10,19-29.

[43] Shvydenko,A.Z.(Ed.).(1987). Regulatory reference materials for forest mensuration of Ukraine and Moldova. Kyiv: Urozhai.

[44] Anuchin, N.P. (1982). Forest mensuration. Moscow: Lesnaia promyshlennost.

\title{
ХАРАКТЕРИСТИКА ДУБОВИХ ЛІСІВ ПРИРОДНОГО ПОХОДЖЕННЯ ДП «ХМІЛЬНИЦЬКЕ ЛГ» ТА ОСОБЛИВОСТІ ЗАПРОВАДЖЕННЯ ЗАХОДІВ ЩОДО ЇХ ВІДТВОРЕННЯ \\ Олег Григорович Василевський ${ }^{1}$, Ігор Степанович Нейко ${ }^{1}$ Юрій Анатолійович Єлісавенко ${ }^{1}$, Михайло Васильович Матусяк ${ }^{2}$
}

\author{
${ }^{1} Д П$ «Вінницька лісова науково-дослідна станція» \\ 21036, вул. Максимовича, 39, м. Вінниця, Україна \\ ${ }^{2}$ Вінницький національний аграрний університет \\ 21008, вул. Сонячна, 3, м. Вінниця, Україна
}

\begin{abstract}
Анотація. У результаті інтенсивного господарського використання дубових лісів регіону значно скорочується частка деревостанів природного походження, що вимагає проведення поглибленого дослідження іх стану, продуктивності та процесів природнього відновлення. Мета наукової роботи - дослідити стан, структуру та лісовідновні процеси дубових лісів для іх подальшого природного відтворення. Для проведення досліджень застосовувалися загальноприйняті методики в лісівництві та методи порівняльної екології для зіставлення динаміки та стану досліджених деревостанів з еталонними. У статті представлені результати досліджень щодо продуктивності та стану природних лісів у межах державного підприємства «Хмільницьке лісове господарство». Було з’ясовано, що природні дубові насадження представлені 7-ма типами лісу, переважно у свіжій грабовій діброві (площа - 471 га). Відповідно до отриманих результатів встановлено, що в межах досліджуваного підприємства переважають природні дубові деревостани вегетативного походження (528,6 га). В основному вони представлені насадженнями 11-го класу віку (188,0 га). Переважають високо-бонітетні дубові насадження 1-го класу бонітету. Стиглі та перестійні насадження мають дещо нижчу продуктивність (2-й клас бонітету, повнотою 0,6-0,7). Найбільшим загальним запасом характеризуються насадження 11-го класу віку. Максимальні середні запаси характерні для деревостанів 9-го класу віку (290 м³/га). Встановлено, що найбільша участь дуба у складі деревостанів (9-10 одиниць) у насадженнях 9-10 класів віку. У результаті проведених досліджень виявлено, що природне поновлення дуба зосереджене переважно у свіжих сугрудах (свіжа грабова судіброва) у насадженнях за участю сосни звичайної та дуба звичайного. Густота природного поновлення становить 1-3 тис. шт/га. Практична цінність роботи полягає у можливості запровадження основних засад ведення лісового господарства, спрямованих на вирощування стійких високопродуктивних деревостанів дуба звичайного шляхом більш повного використання природного поновлення
\end{abstract}

Ключові слова: дуб звичайний, природні насадження, модальні деревостани, високобонітетні деревостани, типи лісу, лісовідновлення, природне поновлення 